\title{
The Lateral Roots of Amyelon radicans, Will., and their Mycorhiza.
}

\author{
BY \\ T. G. B. OSBORN, B.Sc. \\ Assistant Lecturer in Botany in the University of Manchester.
}

With Plates XLVI and XLVII.

4 MYELON RADICANS was described by Professor Williamson (22) $A$ in his fifth memoir, 'On the Structure and Organization of the Fossil Plants of the Coal-Measures ' (1874), as the root of Sphenophyllum, but has since been shown to be the root of Cordaites. In his description, which is mainly concerned with the big roots that have undergone secondary thickening, he refers to groups of lateral rootlets. His Fig. 46, Pl. VII, shows two such bunches of much-branched roots. These are, he says, arranged irregularly on the periphery, and not definitely as in Stigmaria.

As far as I am aware this is the only description of the small roots. Solms-Laubach (16) gives a short account of Amyelon, based on that of Williamson. The root is given amongst those of uncertain affinity.

Renault (11) has described the roots of Cordaites, together with other parts of the plant from Autun. The species described by him have a diarch root, and the periderm forms in the outer cortex. Another difference from Amyelon radicans is that in his specimens the phloem is not preserved.

Scott's 'Studies' (13) also contain a short account of Amyelon as the root of Cordaites, but no mention is made by him of the lateral rootlets. The periderm is stated by him to be deep-seated in its origin.

At the suggestion of Mr. D. M. S. Watson, I examined some slides of Amyelon, with a view of seeing if these remarkable bunches of rootlets might correspond in any way with the 'root-tubercles' of recent plants, in which he knew me to be interested. I have found evidence that this supposition is probably correct, and that the tufts of short, much-branched roots were probably of the nature of 'coralline roots'. I wish here to express my deep indebtedness to $\mathrm{Mr}$. Watson for calling my attention to this point, and for most generously placing his slides, some of which he had made for the purpose, at my disposal. The slides on which this 
investigation is principally based are : A 275, 28I, 282, 283 $a$ and ser., in Mr. Watson's collection, and $\mathrm{R} 707,7 \mathrm{I} 6$ in the Manchester Museum. I have also to thank Dr. Smith Woodward, Keeper of the Geological Department, British Museum (Nat. Hist.) for facilities to examine the Williamson Collection, in which I found numbers $93 \mathrm{I}$ and 932 to be specially useful.

In spite of the common occurrence of mycorhiza amongst recent plants, only one case has been recorded from the Coal Measures. In 1902 Professor Weiss (21) described from this laboratory a small rhizome that appears to have had an undoubted mycorhizic habit. The material in this case was a petrifaction from the Halifax Hard Bed, which is renowned for the beauty of its preservations. In this respect he was more fortunate than I have been in the material here used. All the slides examined in this investigation have been cut from material from Shore or Oldham, at which places Amyelon is particularly abundant. Though the preservation of cellstructure is excellent, the detail in many cases is necessarily not so clear, owing to the contents being of the same brownish colour as the cell-walls. In spite of this difficulty it has been possible to make out an abundant occurrence of hyphae in some of the cells.

An examination of an unthickened and uncrushed rootlet (P1. XLVI, Fig. 2), which may be as much as $1.5 \mathrm{~mm}$. in diameter, shows a wide cortex, consisting of two well-defined zones. The outer cortex is of parenchymatous cells, often of small radial diameter. In some specimens an epidermis appears to be distinguishable by its more distinct outer wall, and the more regular shape of the cells. The cells of this outer region are elongate in longitudinal section, and are almost without exception void of contents, so that it is clearly distinguishable from the succeeding zone. In the inner cortex the cells are also of thin-walled parenchyma, larger than those of the preceding region, and irregularly hexagonal in transverse section. They are somewhat elongate when seen longitudinally. In contradistinction to the cells of the outer cortex, the cells here frequently have a dark cell contents. In some cases this occupies the whole cell, though in others it appears to have contracted towards the walls, or to form a more or less central mass with connecting strands to the walls. These masses of cell contents are apparently tangled knots of fungal hyphae filling the entire cell. In those cases where the contents are contracted, the hyphae appear to have been absorbed by the host plant, the indigestible residue being left. Such is usually the case with recent plants, and has been noted by Weiss for Mycorhizonium.

Some cells appear to be perfectly empty, though well preserved, as if the fungus had not affected them in any way. This invasion of certain cells and omission of others by the symbiotic fungus has been commented upon by Groom (3) in Thismia Aseroe. 
There is a well-marked endodermis in the cells of which no fungus is apparent. This encloses a phloem of elongate, thin-walled cells, which are usually in a good state of preservation. The transverse walls are slightly oblique.

The rootlets are usually diarch. This point was not known to Williamson when he described them originally, but the following observations can be seen in his manuscript catalogue of slides in the British Museum. 'There is obvious evidence that the vascular bundle originated in a bipolar manner and may be centripetal in its further development; this fact was not observed when Memoir 5 was written.' The diarch origin is very well shown in some of the younger rootlets in Mr. Watson's slides, two groups of protoxylem being visible separated by a few thin-walled elements not yet lignified. At the same time triarch rootlets are not uncommon. I have not seen any tetrarch or pentarch rootlets, though in full-grown roots with secondary thickening this condition is to be met with not infrequently. It may have been that only the primary roots had the larger numbers of protoxylem-groups, and the chance of finding these is, of course, not great. In longitudinal section the tracheids are seen to be spiral in the protoxylem. The rest of the centripetal wood has scalariform tracheids with oblique ends. The tracheids of secondary growth are of typical Cordaitean structure with bordered pits.

In slide A 28I I have been fortunate enough to come across a longitudinal section of a root apex (Pl. XLVI, Fig. 3). There is every reason to believe that this belongs to Amyelon, though there is no actual connexion. There are a number of unmistakable young rootlets near ; these are the only well-preserved roots on the slide, and it agrees with them in every way that I have been able to compare them.

A well-marked root-cap, triangular in shape, and of presumably corky cells (measured across which, the root is about $.4 \mathrm{~mm}$. in diameter), protects the meristematic zone. Unfortunately the section is not absolutely median, so I am unable to trace the full extent of this tissue. The few cells that are visible are quite small $(8 \mu)$ and very thin walled; the dermatogen, periblem, and calyptrogen are not distinguishable as is usual in Gymnosperms. Petrifaction appears to have occurred at a period of rest, for behind this region rapid differentiation occurs, the elements derived from the periblem and pleurome being easily distinguishable. Only one spiral tracheid is to be seen against the latter cells, which otherwise are elongate and parenchymatous. The fungus is absent from the growing region. About I mm. from the apex (the bit of root is but $1.5 \mathrm{~mm}$. long) traces of hyphae are to be seen running longitudinally in the inner cortex. Infection of the rootlets appears to have been from behind forwards as they elongated.

The rootlets appear to have had a typical endogenous origin. Before secondary thickening began in the roots, before periderm had begun to 
form, the rootlet that was to become the main one of the group pierced the cortex. It seems to have had its origin in the pericycle opposite one of the protoxylem groups. Pl. XLVI, Fig. I, shows the root-trace passing through the secondary wood from opposite one of the protoxylems of a triarch root. This rootlet, which may be regarded as the main one of a group, appears to have developed a very wide cortex zone, which is seen in the section; and, in some cases, the periderm of the root is continued into the rootlet with probably one cork cambium.

Branching of this rootlet was very frequent, but there is no sign of definite arrangement of the branches. As the rootlet bearing them was diarch they were probably arranged in two rows, as in the case of the tubercles of Podocarpus (Van Tieghem, 19) though this is not apparent from the sections. These branches of the main rootlet divided again almost immediately (Pl. XLVI, Fig. I) ; possibly more than once, for there is always a large number of rootlets near the point of origin of a group. Once the tuft was produced, the individual rootlets seem to have run some distance (certainly some 2 or $3 \mathrm{cms}$.) without branching again. In the last part of their course they appear to have run in and out of the mass of débris with which they are found in the manner of Stigmarian rootlets. They may constantly be seen burrowing through fragments of stems and even older Amyelons. In general appearance it will have been seen that the rootlets are not unlike those of Stigmaria; which resemblance Williamson commented on, both in his memoir and in his catalogue.

The origin of the periderm is stated by Williamson to have been in a peculiar manner-namely, by radial elongation of the cells of the outer cortex, which subsequently formed numerous radial walls. This appears at first sight to be possible, if not probable, when an old Amyelon is examined. It is not, however, borne out by the younger stage. The periderm has been stated by Renault to have been superficial in its origin (loc. cit.). Scott, however, states it to be deep-seated in Amyelon radicans, and my observations confirm this. The rootlet, when the metaxylem was formed, produced a cork cambium immediately outside the endodermis, as is usual in Gymnosperms. The whole of the cortex would then be sloughed, the inner mycorhizal zone included (Pl. XLVI, Fig. 4). This is exactly what occurs in Podocarpus.

The fungus is apparent in the cortex as hyphae, with a diameter of about $4 \mu$. Septa are either absent or very rare. In the outer cortex the hyphae are to be seen best in longitudinal section, when they are noticed running apparently from the exterior to the interior of the cell (Pl. XLVII, Fig. 5). The inner cells may be divided, as Werner Magnus (6) has shown, into host cells (Pilzwirthzellen), and digestive cells (Verdaunngszellen). In the former the hyphae are noticed to coil around the exterior of the cell (Pl. XLVII, Fig. 6). In places the walls are dilated to about $I \frac{1}{2}$ times 
their former diameter ; in the latter cells the hyphae appear to have entered the cell and grown around a central nucleus. P1. XLVII, Fig. 7, shows the beginning of such a stage, of which Figs. 8 and 9 may be later stages in the absorption of the hyphae. Dilations of the hyphae are apparent here also ; but the large bladder-like growths, which Groom has described, are not to be seen. In the cortex of the rootlets that are apparently full-grown, and are about to form a periderm, there are to be observed large knob-like growths with thickened walls that are apparently terminal on the hyphae, and are about $.05 \mathrm{~mm}$. in diameter (Pl. XLVII, Fig. 6). These I take to be a form of resting-body which the fungus forms to carry it over the period during which the cortex will be sloughed, and before it has an opportunity of infecting a fresh rootlet. They are not unlike those swollen hyphae figured by Seward, but they are formed in definite connexion with the rest of the mycelium, and in roots which, there is every reason to believe, were healthily growing ones, and not detached fragments of decaying vegetable matter. Quite recently, while examining roots of Podocarpus cupressina, I have found exactly similar dilations terminal on the hyphae, in the cortex of the roots at the time that cork-formation had set in. This parallel I consider particularly useful, as it meets the possible objection that the bladder formations are sporangia of a parasitic fungus.

All sign of spore-formation is lacking, though some sign might be expected to be present in either a saprophyte or a parasite.

It is manifestly impossible to offer any suggestion as to the relationship or systematic position of the fungus; and it is quite unsafe to formulate any theory of Phycomycetous relationship based on the general absence of septa. To quote Shibata, 'Das Fehlen der Querwände in den Hyphen beweist hier nichts, da die Septirung oftmals in intracellular-lebenden Mycelien ausbleibt.'

The relationship of the fungus to the lateral roots of Amyelon is a matter on which there may reasonably be some uncertainty. It is well known that the saprophytic fungi occur quite commonly with the remains of higher Palaeozoic plants. Seward (14) has given a collected account of them in the first volume of his 'Fossil Plants', and there is also the large monograph by Meschinelli (7), though this is not confined to Palaeozoic specimens. They are omnipresent amongst decaying vegetation to-day, so that there is nothing to cause surprise that similar destructive agencies should have existed in the Coal Measure Period.

The fungus in question, however, hardly gives the impression of being a saprophyte. In the first place the preservation of the material is against this, for it is equally good for both fungus and roots. These latter are in many cases admirably preserved, e.g. the root apex, and do not give the impression of being decaying pieces of vegetable matter on which the fungus was feeding, but rather sound and living rootlets, at the time that infection 
occurred (cf. Weiss). Again, the hyphae are confined to one region of the roots, namely to the inner cortex. Traces of the hyphae are, it is true, to be found in the epidermis and the outer cortex, but they are comparatively rare. The fungal filaments, when seen there, occur singly, and appear to be running from the exterior inwards, or longitudinally with the root. There are, as it has been pointed out, no dilations or branchings in this region. Moreover, I have never observed them in the phloem region or in the wood. It should also be remembered that they are absent from all the tissues of the main roots that have undergone secondary thickening.

The possibility of parasitism has also to be considered. Oliver (10) has described parasitic fungi from the Palaeozoic era. The argument of restriction of infection, cited against saprophytism, also holds here. A parasitic fungus might be expected either to ramify over the whole of the tissues, or to attack such a region of soft tissue as the bast, as in the case of Armellaria melleus, to take a common instance. This, however, is not the case.

The constancy with which the fungus appears is also against its being of the nature of a disease. In all cases where the preservation is sufficiently good in material, from both different blocks and different localities, hyphae are to be observed. It is hardly to be expected that a fungus would have so widespread an occurrence, unless there were a great epidemic, or else some vital reason for its presence.

This last explanation, that of a symbiosis, seems to be the most probable relationship. First the fact, that the root has the tendency to branch so frequently forming definite tubercles, is strongly reminiscent of Myrica, Alnus, \&c. The division of the cortex into infected and noninfected regions, and the occurrence of knots of hyphae in some only of the cells, reminds one of similar cases described by Frank (2), Warlich (20), Groom (3), Werner Magnus (6), Shibata (15), \&c. Weiss, in describing Mycorhizonium, has commented upon the frequency with which some form of symbiotic union is to be met with among recent plants ; instancing Janse's paper (5) in the Buitenzorg 'Annales'. The structure described by Weiss is, however, the only recorded case among Palaeozoic plants.

In the case of recent Gymnosperms some union of the spermophyte with a thallophyte is of common occurrence. The case of Cycas is well known. Dacrydium and Podocarpus have tubercles, the Coniferae generally have an ectotropic mycorhiza. It need not, therefore, be a matter of surprise that their Palaeozoic ancestors should have had a similar relationship.

The very interesting question of the biologic conditions under which Cordaites lived appears to be somewhat elucidated by these observations. It has been pointed out that in some respects the fungus has a resemblance to that found in Podocarpus. There is, however, no formation of nodules, as in the latter plant, but rather a production of numerous short and much- 
branched lateral roots at intervals along the main ones. Whether this frequent branching is a direct outcome of the presence of the fungus, which would exert a stimulus on the tissues, or not, is a point that cannot, of course, be decided. From analogy with recent plants, this seems highly probable.

Recent work on the physiology of mycorhizic plants seems to show that the relationship of the fungus to the host is a very vital one. And whether it is one in which the host benefits by obtaining a more abundant supply of mineral salts, from a soil rich in humus, which it is unable to do efficiently without the aid of the fungus, according to $\operatorname{Stahl}(17)$, or whether the endophyte has the property of fixing atmospheric nitrogen, so giving its host a larger quantity of nitrates than it could otherwise obtain (Nobbe and Hiltner, 9, and Hiltner, 4) the general result seems fairly established.

Myrica (when it grows in swampy soil), Almus and Elaeagnus all produce short fleshy roots caused by either a fungus or a bacterium and inhabited by it, and the benefit accruing to the spermophyte in at least one of these cases has been strikingly demonstrated (Möller, 8). It is not unreasonable to suppose in that case that the rootlets in Amyelon, which in many respects seem to have had a similar structure to recent mycorhizal roots, may have had a similar function.

Stopes and Watson (18), in their paper on 'Coal Balls', have given cogent reasons to prove that these concretions were formed in situ by gradual petrifaction of vegetation at the bottom of a brackish swamp. The conditions of life in such a locality are exactly of the kind that would lead one to expect the production of root-tubercles on some of the plants growing there. The soil would be deficient in nitrates, while it would be rich in humic acid. Mycorhiza are frequently associated with plants liable to suffer from drought, or growing in a soil abundant in humus. These are the conditions that we might expect in a saline marsh, the drought being physiological rather than physical (Schimper, 12). Indications are not lacking that the leaves of some species of Cordaites (C. crassus and angulostriatus) were possessed of xerophyllous characters (Renault and Scott).

It has been pointed out that these rootlets are found mingled with, and growing amongst, a mass of débris of other plants of all kinds. While the Amyelon roots are frequently well preserved, the fragments of vegetation around are often much decayed. It is quite easy to see that such would be the appearance in a petrifaction formed in situ, if the Cordaites roots were growing there, the other plants being mere débris.

These, indeed, are very much the conditions in which Myrica Gale is to be found growing around the Cheshire meres to-day, only the water is fresh and not salt, as it probably was in a Coal Measure swamp. An examination of these rootlets has led me to the conclusion that they were probably borne by plants adapted to such conditions as would exist in the kind of marsh that Stopes and Watson describe. 


\section{SUMMARY.}

I. A redescription is given of the tufts of short much-branched roots borne at intervals on Amyelon radicans, and originally described by Williamson in 1874 .

2. The lateral roots are found to have a wide cortex divisible into two regions.

3. The inner cortex of all specimens examined is found to contain, more or less abundantly, dark cells, many of which on examination show evident fungal hyphae.

4. The fungus occurs in knots of apparently non-septate hyphae. These bear in some cases terminal vesicles. There is no trace of any sporeformation.

5. The relationship of the fungus to Amyelon is discussed, and the conclusion arrived at that it was of the nature of a symbiosis.

6. Cordaites was probably a tree, inhabiting saline swamps, and having bunches of coralline rootlets on its roots, such as are known to occur in many recent plants growing under similar conditions.

\section{Literature Cited.}

1. Chevalier, A.: Monographie des Myricacées. Mém. Soc. Sci. Nat. Cherb., xxxii, I9or, p. I2I.

2. Frank : Ueber neue Mycorhiza-Formen. Ber. d. deutsch. Bot. Gesellsch., v, I887, p. 395, and Ueber die physiologische Bedeutung der Mycorhiza, vi, I888, p. 248.

3. Groom, P.: On Thismia Aseroe and its Mycorhiza. Annals of Botany, ix, 1895, p. 327.

4. Hiltner: Lafar's Handbuch der techn. Mykologie, iii, I908, p. 24.

5. Janse, J. M.: Les endophytes radicaux de quelques plantes javanaises. Ann. du Jard. Bot. Buitenzorg, xiv, 1897, p. 66.

6. Magnus, Werner: Studien an der endotrophen Mykorrhiza von Neottia Nidus-avis, L. Jahrb. f. wiss. Bot., xxxv, I900, p. 205.

7. Meschinelli, A.: Fungorum fossilium omnium Iconographia. 1902.

8. Möller, H. : Ueber den Dimorphismus der Wurzelknöllchen der Erbse. Ber. d. deutsch. Bot。 Gesellsch., x, 1892, p. 242.

9. Nobbe and Hiltner: Die endotrophe Mykorrhiza von Podocarpus und ihre physiologische Bedeutung. Landwirth. Versuchsst. li, I90I.

10. Oliver, F. W.: Studies in Fossil Fungi. New Phytologist, ii, 19०3, p. 49.

11. Renault, M. B. : Cours de Botanique Fossile, i, i881, p. 87.

12. Schimper, A. F. W.: Pflanzengeographie, 1898 , pp. 6 and 416.

13. ScotT, D. H. Studies in Fossil Botany, ii, I909, p. 53 I.

14. Seward, A. C. : Fossil Plants, i, 1898, p. 207.

15. Shibata, K. : Cytologische Studien über die endotrophen Mykorrhizen. Jahrb. f. wiss. Bot., xxxvii, 1902, p. 643.

16. Solms-Laubach : Fossil Botany, i89i, p. $3^{6} 3$.

17. Stahl, E. : Der Sinn der Mykorrhizenbildung. Jahrb. f. wiss. Bot., xxxiv, 1900, p. 539.

18. Stopes, M. C., and Watson, D. M. S. : On the present Distribution and Origin of the calcareous Concretions in Coal Seams known as 'Coal Balls'. Phil. Trans. B., cc, 1908, p. I67.

19. Van Tieghem, Ph. : Recherches sur la structure des plantes vasculaires. Ann. des Sci. Nat., Bot., Ser. V, xii, 1870, p. 195 . 
20. WaRlich, W.: Beiträge zur Kenntnis der Orchideen-Wurzelpilze. Bot. Zeitung, I886, pp. $48 \mathrm{I}$ and 498.

21. Weiss, F. E. A Mycorhiza from the Lower Coal Measures. Annals of Botany, xviii, 1904, p. 255. 22. Williamson, W. C. : On the Organization and Structure of the Fossil Plants from the Coal Measures, part v. Phil. Trans., clxiv, I874, p. 4I.

\title{
EXPLANATION OF PLATES XLVI AND XLVII.
}

\author{
Illustrating Mr. Osborn's paper on Amyelon radicans.
}

\section{PLATE XLVI.}

Fig. I. Root surrounded by numerous rootlets. $p x .=$ protoxylem; $p d .=$ periderm; $t . r .=$ bundle trace running to main rootlet of a bunch; $m . r .=$ main rootlet $; m^{\prime} . r^{\prime} .=$ main rootlet of a bunch that left root $(r . t$.$) higher than plane of section; r r_{0}=$ rootlets, lateral branches of $m^{\prime} . r^{\prime}$. showing the way that lateral rootlets branch immediately on leaving the main root.

Fig. 2. Transverse section of rootlet. $x_{0}=$ diarch $x y l e m ; p h .=$ phloem; end. =endoderms; i.c. $=$ inner cortex, cells with dark contents; $0 . c_{.}=$outer cortex.

Fig. 3. Longitudinal section of root apex. $r . c_{0}=$ root cap; $m . c_{0}=$ meristemmatic cells; $p b . c_{0}=$ periblem elements $; p l . c_{.}=$pleurome elements $; p p . v .=$ spiral vessel $; f . c .=$ cells with hyphae

Fig. 4. Transverse section of tetrarch root showing deep-seated origin of periderm. $p x_{0}=$ protoxylem; $x_{0}=$ xylem $; p h_{0}=$ phloem and pericycle $; c_{.} c_{0}=$ cork cambinm $; p d_{0}=$ periderm $; c_{.}=$cortex cut off by periderm.

\section{PLATE XLVII.}

All figures drawn with camera lucida in outline. Reichert, 7a. obj., x8 comps. occ. reduced $\frac{2}{3}$.

Fig. 5. Part of longitudinal tangential section of a rootlet, showing epidermis (epi.) and outer cortex (o.c.) with hyphae cut transversely. i.c. $=$ inner cortex with host cells containing hyphae. A. 282 .

Fig. 6. Cells of inner cortex in transverse section, just before periderm formation. h. $c_{0}=$ host cells; r.b. resting bodies. A. 275 .

Fig. 7. Transverse section of rootlet. Young stage in formation of digestive cells. R. 716.

Fig. 8. Digestive cell in longitudinal section, hyphae disorganizing, a central knot of indigestible matter is forming. A. 282 .

Fig. 9. Transverse section of cells in inner cortex showing late stages in disorganization of digestive cells. A. 282 . 

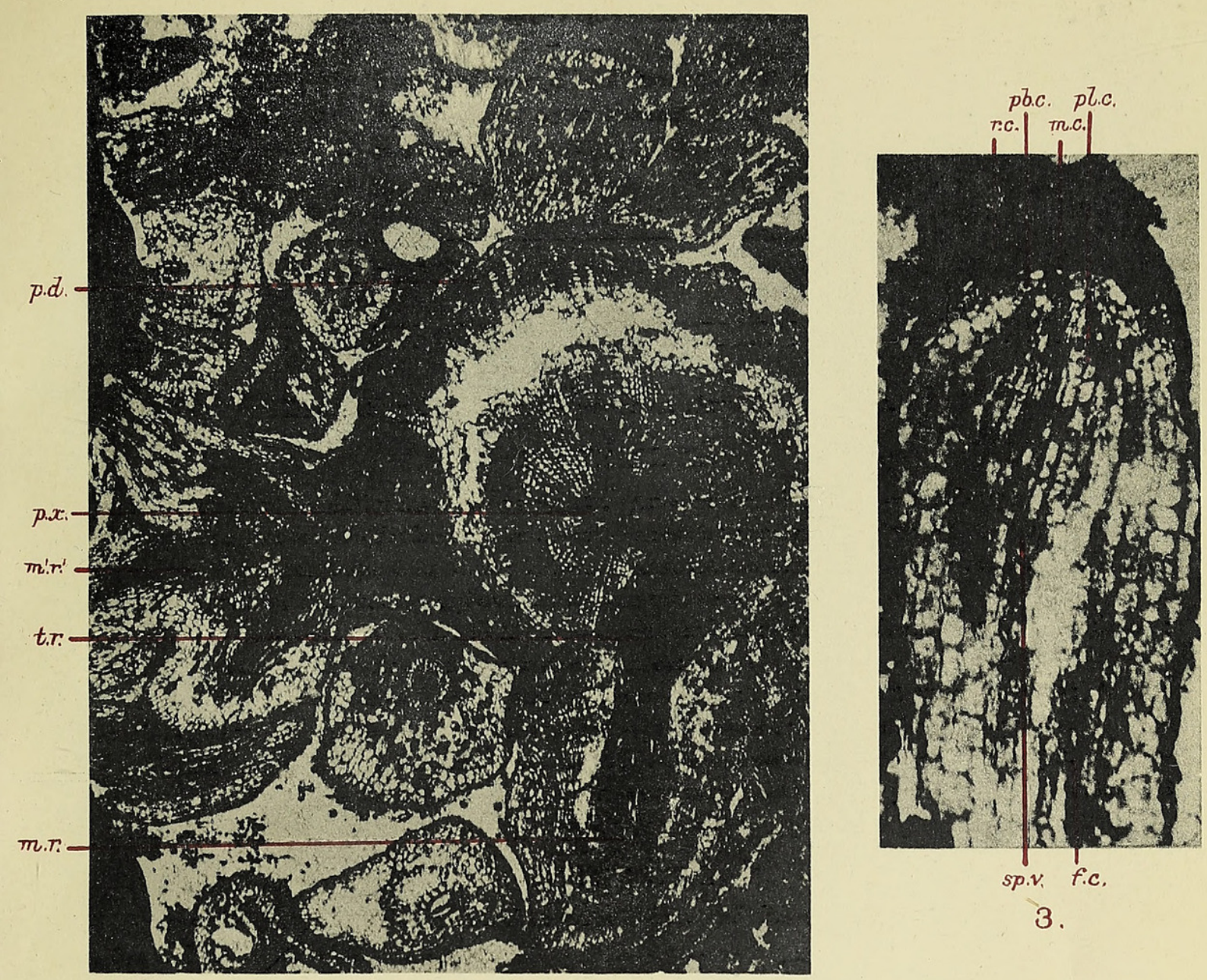

3.

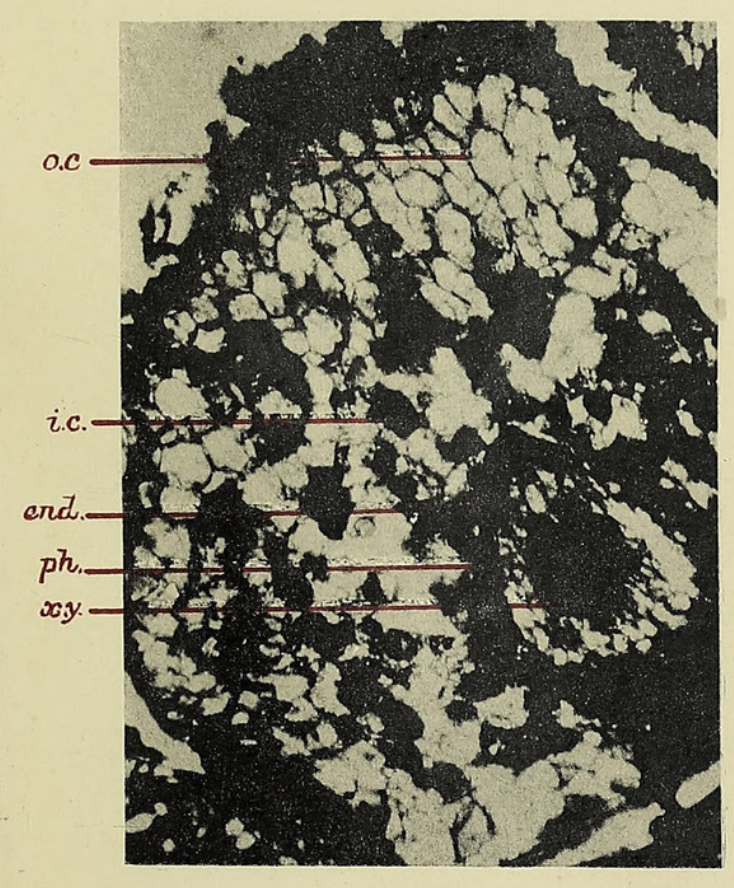

2 .

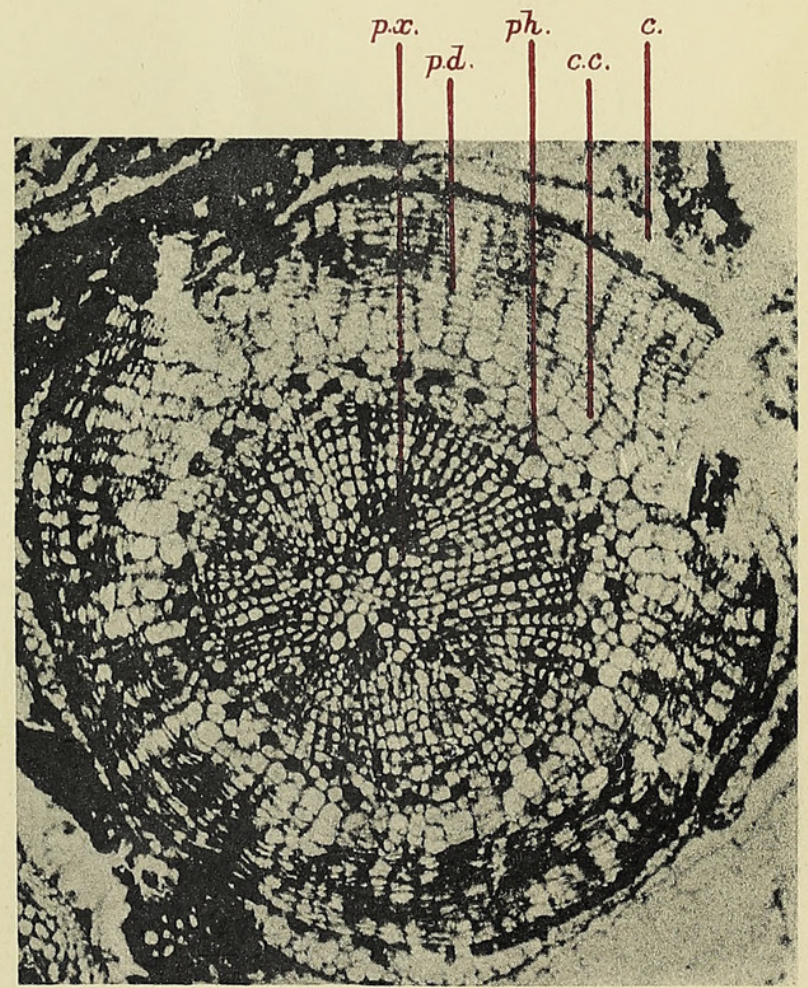

4. 
Annals of Botany

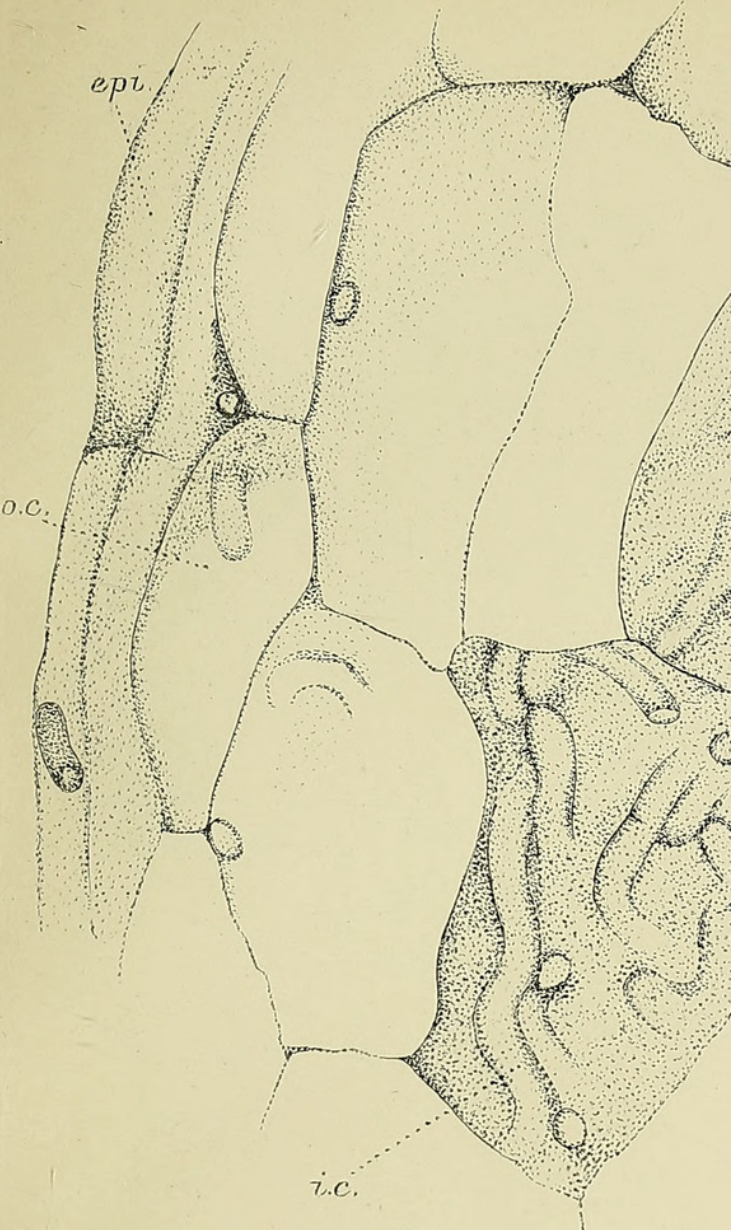

5.

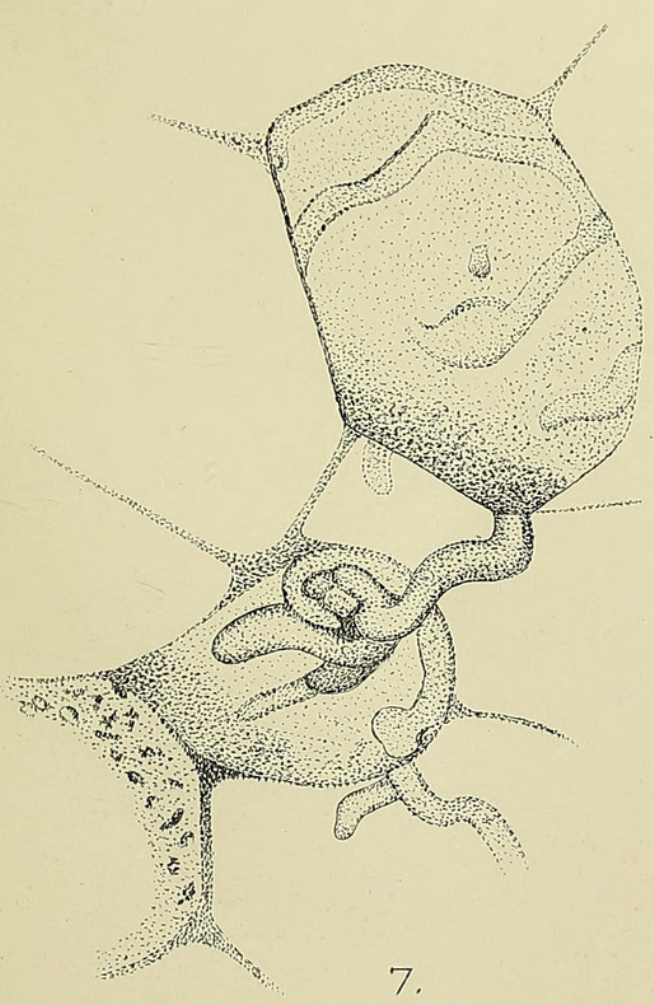

T.G.B. O. del.
Vol.XXIII.PY.XIVII.

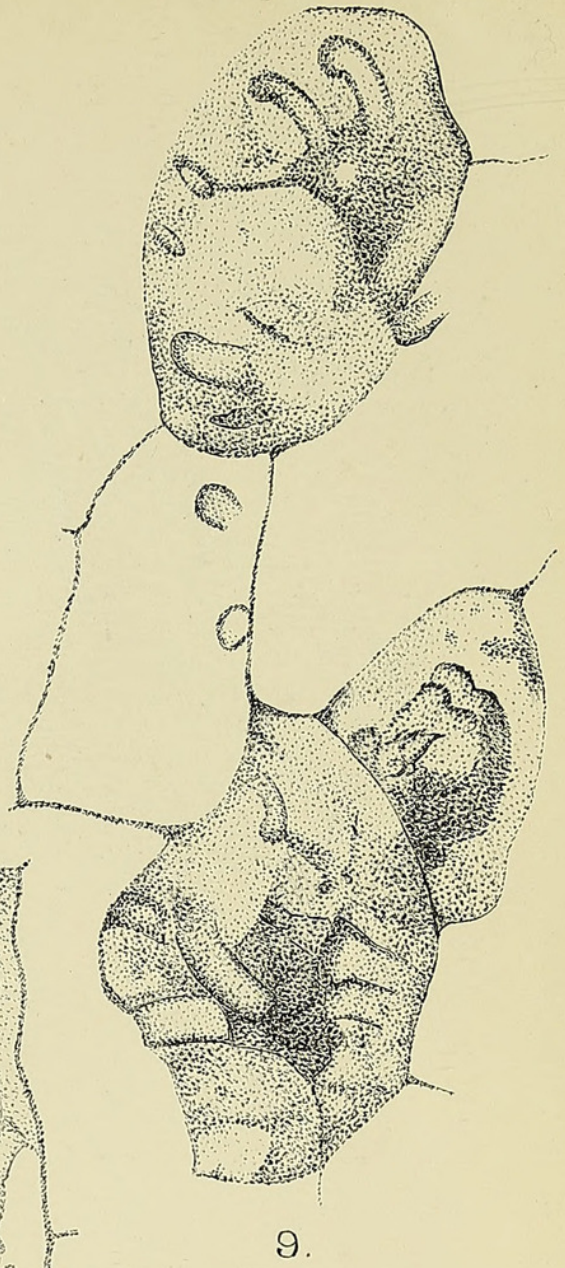

h.c.
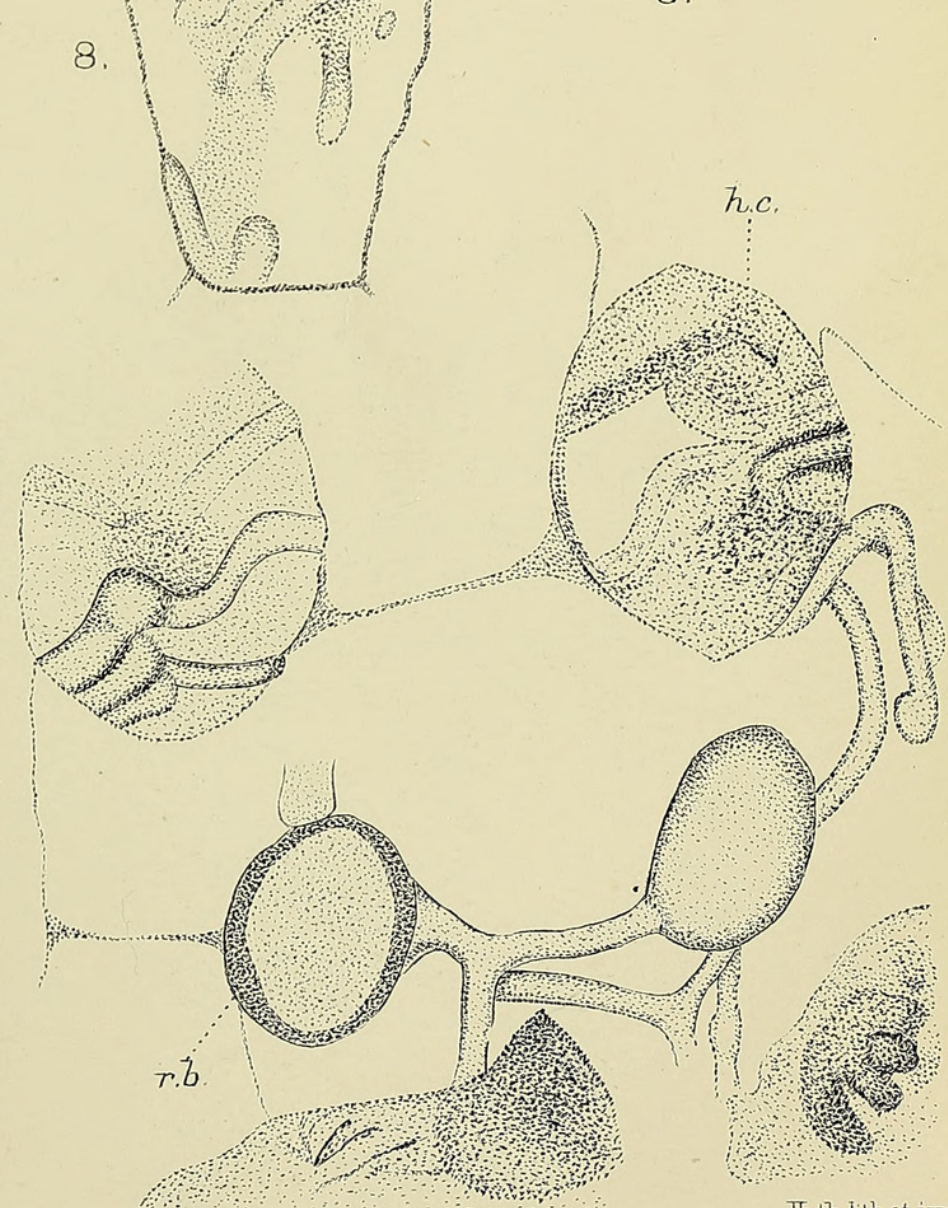

6.

Thith, bilb et int 


\section{$2 \mathrm{BHL}$ Biodiversity Heritage Library}

Osborn, T G B. 1909. "The lateral roots of Amyelon radicans, Will., and their mycorhiza." Annals of botany 23, 603-611.

https://doi.org/10.1093/oxfordjournals.aob.a089242.

View This Item Online: https://www.biodiversitylibrary.org/item/236540

DOI: https://doi.org/10.1093/oxfordjournals.aob.a089242

Permalink: https://www.biodiversitylibrary.org/partpdf/318977

\section{Holding Institution}

Smithsonian Libraries

\section{Sponsored by}

Biodiversity Heritage Library

\section{Copyright \& Reuse}

Copyright Status: Not in copyright. The BHL knows of no copyright restrictions on this item.

This document was created from content at the Biodiversity Heritage Library, the world's largest open access digital library for biodiversity literature and archives. Visit BHL at https://www.biodiversitylibrary.org. 